\title{
A meta-analysis on the application value of gray-scale ultrasound combined with shear wave elastography in the measurement of pelvic floor muscles in primipara
}

\author{
Yi Qu ${ }^{1}$, Huiyuan Sun ${ }^{2}$, Jingjing Chen ${ }^{1}$, Jingjing Bai ${ }^{1}$, Yajing Liu ${ }^{1}$, Yang You ${ }^{3}$ \\ ${ }^{1}$ Department of Nursing, Children's Hospital of Hebei Province, Shijiazhuang, China; ${ }^{2}$ Science and Education Department, Children's Hospital of \\ Hebei Province, Shijiazhuang, China; ${ }^{3}$ Department of Medical Imaging, Fourth Hospital of Hebei Medical University, Shijiazhuang, China \\ Correspondence to: Yang You. Department of Medical Imaging, Fourth Hospital of Hebei Medical University, Shijiazhuang, China. \\ Email: youyoung96@163.com. \\ Response to: Tu J, Fang Q, Zhao A, et al. Discussion on the interpretation of the results and selection of the effect model in a meta-analysis. Ann Palliat \\ Med 2022. doi: 10.21037/apm-21-3819.
}

Submitted Jan 21, 2022. Accepted for publication Feb 18, 2022.

doi: 10.21037/apm-2022-02

View this article at: https://dx.doi.org/10.21037/apm-2022-02

We thank Tu et al. for his comments on our paper, Systematic review and meta-analysis: "Gray-scale ultrasound and shear wave elastography in the diagnosis of primipara pregnancy and delivery", published in journal of Annals of Palliative Medicine (1). We reported in the abstract section of our paper that there were no statistically significant differences in maternal age, body mass index (BMI), gestational age, gestational age at delivery, neonatal weight, and cervical depth between the study and control groups. As you stated, the results showed that the $\mathrm{P}$ values for these indicators were all greater than 0.05 . However, the results were described in the abstract as being significantly different, which may have been due to an error in the way they were conveyed. We apologize for the misunderstanding this has caused you and your readers. However, in the results section of the main text, the analysis and description of these indicators are correctly reported.

The use of different effect models is based on the quality of the underlying data, with a random effects model selected if study-level variability is expected to be meaningful (2). A random effects model can be used for significance testing, rejecting null values for homogeneous effect sizes (3). If the random effects model analysis shows no significant heterogeneity, the fixed effect estimates will be derived. These estimates change only in the presence of significant heterogeneity (4). Therefore, a random effects model was adopted in this study for analysis. In addition, following your suggestion, we used a fixed effect model to analyze the included data. The results showed that there was no obvious heterogeneity in the posterior lip shear wave velocity between the study group and the control group in figure 13, and the $95 \%$ confidence interval (CI) range, $Z$ value, and $\mathrm{P}$ value were consistent with the results in our paper. Therefore, the use of a random or fixed effects model for this indicator does not affect the results of the data analysis.

After repeating our analysis and confirming the findings, we found that the points raised by Tu et al. have no influence on the results of our research.

\section{Acknowledgments}

Funding: None.

\section{Footnote}

Provenance and Peer Review: This article was commissioned by the editorial office, Annals of Palliative Medicine. The article did not undergo external peer review.

Conflicts of Interest: All authors have completed the ICMJE uniform disclosure form (available at https://apm. amegroups.com/article/view/10.21037/apm-2022-02/coif). The authors have no conflicts of interest to declare.

Ethical Statement: The authors are accountable for all aspects of the work in ensuring that questions related 
to the accuracy or integrity of any part of the work are appropriately investigated and resolved.

Open Access Statement: This is an Open Access article distributed in accordance with the Creative Commons Attribution-NonCommercial-NoDerivs 4.0 International License (CC BY-NC-ND 4.0), which permits the noncommercial replication and distribution of the article with the strict proviso that no changes or edits are made and the original work is properly cited (including links to both the formal publication through the relevant DOI and the license). See: https://creativecommons.org/licenses/by-nc-nd/4.0/.

Cite this article as: Qu Y, Sun H, Chen J, Bai J, Liu Y, You Y. A meta-analysis on the application value of gray-scale ultrasound combined with shear wave elastography in the measurement of pelvic floor muscles in primipara. Ann Palliat Med 2022;11(3):1155-1156. doi: 10.21037/apm-2022-02

\section{References}

1. Qu Y, Sun H, Chen J, et al. Systematic review and metaanalysis: gray-scale ultrasound and shear wave elastography in the diagnosis of primipara pregnancy and delivery. Ann Palliat Med 2021;10:11664-77.

2. Spineli LM, Pandis N. Meta-analysis: Random-effects model. Am J Orthod Dentofacial Orthop 2020;157:280-2.

3. Yamaguchi Y, Maruo K, Partlett C, et al. A random effects meta-analysis model with Box-Cox transformation. BMC Med Res Methodol 2017;17:109.

4. Jackson D, Turner R. Power analysis for random-effects meta-analysis. Res Synth Methods 2017;8:290-302. 